\title{
Genotoxicity of Polycyclic Aromatic Hydrocarbons and Nitro-Derived in Respirable Airborne Particulate Matter Collected from Urban Areas of Rio de Janeiro (Brazil)
}

\author{
Claudia Ramos de Rainho, ${ }^{1}$ Sérgio Machado Corrêa, ${ }^{2}$ José Luiz Mazzei, ${ }^{3}$ \\ Claudia Alessandra Fortes Aiub, ${ }^{4}$ and Israel Felzenszwalb ${ }^{1}$ \\ ${ }^{1}$ Universidade do Estado do Rio de Janeiro. Instituto de Biologia Roberto Alcantara Gomes, Departamento de Biofísica e Biometria, \\ Laboratório de Mutagênese Ambiental, 20551-030 Rio de Janeiro, Brazil \\ ${ }^{2}$ Universidade do Estado do Rio de Janeiro, Faculdade de Tecnologia, Departamento de Química Ambiental, 27537-000 Resende, \\ RJ, Brazil \\ ${ }^{3}$ Fundação Oswaldo Cruz, Farmanguinhos Plataforma de Métodos Analíticos, 21040-360 Rio de Janeiro, Brazil \\ ${ }^{4}$ Universidade Federal do Estado do Rio de Janeiro, Instituto Biomédico, Departamento de Genética e Biologia Molecular, \\ Laboratório de Genotoxicidade, 20211-040 Rio de Janeiro, Brazil
}

Correspondence should be addressed to Israel Felzenszwalb; uerj.felzen@gmail.com

Received 2 April 2013; Accepted 11 April 2013

Academic Editor: John B. Vincent

Copyright (c) 2013 Claudia Ramos de Rainho et al. This is an open access article distributed under the Creative Commons Attribution License, which permits unrestricted use, distribution, and reproduction in any medium, provided the original work is properly cited.

\begin{abstract}
Air pollution toxic effects are mainly attributed to small inhalable particulates with an aerodynamic diameter of less than $2.5 \mu \mathrm{m}$ (PM 2.5). Our objective was to investigate mutagenic and clastogenic activity in PM samples collected in Rio de Janeiro. Samples were collected using a high-volume sampler at three sites: with low traffic and (2) and (3) with a heavy traffic. Six polycyclic aromatic hydrocarbons (PAHs) were quantified by gas chromatography/mass spectrometry (GC/MS). Salmonella typhimurium TA98 and the derivative strains YG1021 and YG1024 were used in mutagenicity assays in the presence of organic extracts (10-50 $\mu \mathrm{g} / \mathrm{plate})$ with and without exogenous metabolization. Allium cepa test was performed to evaluate possible cytotoxic and clastogenic activities. The highest PM $2.5 \mu \mathrm{m}\left(132.73 \mu \mathrm{m} / \mathrm{m}^{3}\right)$ and PAH values $\left(1.22 \mathrm{ng} / \mathrm{m}^{3}\right.$ for benzo(a)pyrene) were detected at site 3 . High mutagenic frameshift responses in absence and presence of metabolic activation were detected at site 3 . The participation of nitroarenes and dinitroarenes was detected in the total mutagenicity of the extracts studied. The cytotoxic effect and the abnormalities detected by Allium cepa test can be attributed to the PAH nitroderivatives in the organic extracts. Evaluation of the genotoxicity of urban airborne particulate matter is important as a basis for decision making by regulatory authorities.
\end{abstract}

\section{Introduction}

Epidemiological studies have demonstrated that exposure to urban particulate matter (PM) is associated with several adverse health effects. Long-term exposure to high concentrations of PM increases the risk of lung cancer, respiratory diseases, and arteriosclerosis, whereas short-term exposure peaks can cause exacerbation of several forms of respiratory diseases, including bronchitis and asthma, as well as changes in heart rate variability $[1,2]$. Studies conducted in Rio de
Janeiro city showed an association between PM exposure and mortality from lung cancer $[3,4]$, reduced respiratory capacity amongst children [5], and increased pediatric visits to treat symptoms of bronchial obstruction [6].

The toxic effects of PM are mainly attributed to small inhalable particulates with an aerodynamic diameter of less than $2.5 \mu \mathrm{m}$ (PM 2.5). Because of their large specific surface, these particulates can adsorb various organic substances, such as polycyclic aromatic hydrocarbons (PAHs), nitroaromatic hydrocarbons (nitro-PAHs), and oxygenated 
aromatic hydrocarbons (oxy-PAHs) [7]. According to [8], the mutagenicity of airborne particulate can result from at least 500 identified compounds from various chemical classes. Mutagenic nonsubstituted PAHs are the most studied and well-known compounds; however, more recently, nitro- and oxy-PAHs have been shown to be very important because of their strong biological activity [9-11].

The Salmonella/microsome microsuspension assay has been used for large, multisite, and/or time-series studies, for bioassay-directed fractionation studies, for identifying the presence of specific classes of mutagens, and for siteor source-comparisons of relative levels of airborne mutagens [8]. The use of strains of Salmonella typhimurium with different metabolic capacities can indicate the class or classes of compounds present in an environmental sample [11-13].

Higher plants are recognized as excellent genetic models to detect environmental mutagens and are frequently used in monitoring studies. Among the plant species, Allium cepa has been used to evaluate DNA damages, such as chromosome aberrations and disturbances in the mitotic cycle. Employing the Allium cepa as a test system to detect mutagens dates back to the 30s. It has been used to this day to assess a great number of chemical agents, which contributes to its increasing application in environmental monitoring. It is easily handled and has advantages over other short-term tests that require previous preparations of tested samples, as well as the addition of exogenous metabolic system [14].

The objective of the present work was to investigate mutagenic and clastogenic activities in the PM samples collected at three sites in Rio de Janeiro.

\section{Material and Methods}

2.1. Sampling Sites. The samples were collected at three sites in Rio de Janeiro: the campus of the Rio de Janeiro State University (site 1), Avenida Brasil (site 2), and Rebouças tunnel (site 3) between August and October 2010 (winter and spring seasons). Site 1, with low traffic, is located in a residential area of the city's north zone. Site 2 has heavy traffic ( 250,000 vehicles/day) and is the city's biggest highway, covering $58 \mathrm{~km}$ in length and crossing 27 neighborhoods. Site 3 has heavy traffic ( 190000 vehicles/day). It connects the north and south zones of the city and is $2.8 \mathrm{~km}$ long [15].

Airborne PM 2.5 samples were collected on fiberglass filters (E558 X 10IN, $254 \mathrm{~mm} \times 203 \mathrm{~mm}$ ) using a high-volume collector (AVG MP 2.5, $1.13 \mathrm{~m}^{3} / \mathrm{mim}$ ) for $24 \mathrm{~h}$ for site 1 and site 2 and $6 \mathrm{~h}$ for site 3 . Four monthly samplings were performed for each site of study. The filters were weighed and stabilized before and after sampling (45\% humidity) for the determination of particulate concentration, expressed in $\mu \mathrm{g} / \mathrm{m}^{3}$ units of sampled air [16-18]. At the end of the sampling, the filters were combined to form a pool sample.

2.2. Extraction of Organic Compounds. Half of each filter was sonicated in three rounds of $10 \mathrm{~min}$ each using dichloromethane (DCM, CASRN. 75-09-2, TediaBrazil, Brazil, purity 99.9\%). The extracts were concentrated to $15 \mathrm{~mL}$ in a rotating evaporator and filtered in a Teflon membrane $(0.5 \mu \mathrm{m})$. The concentration of extractable organic matter (EOM, in $\mu \mathrm{g} / \mathrm{m}^{3}$ ) was calculated. Prior to bioassays, the organic extract was dried at $4^{\circ} \mathrm{C}$ and resuspended in $5 \mu \mathrm{L}$ dimethyl sulfoxide (DMSO, CASRN. 67-68-5, Synth, Brazil, purity 99.9\%) [16-18].

2.3. Analysis of Polycyclic Aromatic Hydrocarbons (PAHs). PAHs were identified and quantified by gas chromatography/mass spectrometry (GC/MS), using a Varian system consisting of a gas chromatograph (450-GC) with a split/splitless injector $1177 \mathrm{~S} / \mathrm{SL}$ (kept at $300^{\circ} \mathrm{C}$ ) coupled to the mass spectrometer detector (MS 220). The ion trap $\left(250^{\circ} \mathrm{C}\right)$, manifold $\left(280^{\circ} \mathrm{C}\right)$, and transfer line $\left(280^{\circ} \mathrm{C}\right)$ were maintained at constant temperatures. PAHs were identified by mass similarity and by the retention time of the components in a commercial standard kit (Supelco, PAH610-S). Quantification was based on five calibration points, which were constructed from each standard for all the target analytes, ranging from 10 to $250 \mathrm{pg} / \mu \mathrm{L}$. Injections $(2.0 \mu \mathrm{L})$ were splitless, with the split opened after $0.5 \mathrm{~min}$, and helium 5.0 was used as the carrier gas. A VF-5MS column $(30 \mathrm{~m} \times 0.25 \mathrm{~mm} \times 0.25 \mu \mathrm{m})$ was employed. The column and septum purge flows were set at 1.6 and $3 \mathrm{~mL} / \mathrm{min}$, respectively. The oven temperature program was as follows: $70^{\circ} \mathrm{C}$ for $4 \mathrm{~min}$ then heating to $300^{\circ} \mathrm{C}$ at $10^{\circ} \mathrm{C} / \mathrm{min}$. This directive was designed for the analysis of the sixteen main priority PAHs, but only six were detected: phenanthrene, fluoranthene, pyrene, benzo(a)anthracene, chrysene, and benzo(a)pyrene. The limits of quantification were determined from the minimum point in the calibration curves. Limits of detection were determined from $\mathrm{PAH}$ concentrations, which resulted in a signal-to-noise ratio of $3: 1$. The results were expressed in $\mathrm{ng} / \mathrm{m}^{3}[19]$.

2.4. Salmonella/Microsome Assay. The organic extracts were assayed for mutagenicity using the microsuspension version [20] of the Salmonella/microsome assay [21]. Salmonella typhimurium TA98 (frameshift strain) and the derivative strains YG1021 (nitroreductase overproducing) and YG1024 (O-acetyltransferase overproducing) [22] were used, with and without metabolic activation (S9 mix fraction). Five concentrations of each sample $(10,20,30,40$, and $50 \mu \mathrm{g} /$ plate $)$ were tested in triplicate. The samples were preincubated for $90 \mathrm{~min}$. All assays were carried out under yellow light and in the presence of negative (dimethyl sulfoxide-DMSO solvent, $5 \mu \mathrm{L} /$ plate) and positive (4-nitroquinoline oxide4NQO, $0.5 \mu \mathrm{g} /$ plate, CASRN. 56-57-5 and 2-aminofluorene2AF, $1 \mu \mathrm{g} /$ plate, CASRN. 153-78-6 from Sigma Chemical Company, St. Louis, MO, USA) controls. Plates were incubated in the dark at $37^{\circ} \mathrm{C}$ for $72 \mathrm{~h}$; after which time, revertants were counted. The sample was considered positive when a mutagenesis value of at least twice the negative value, a significant ANOVA $(P<0.05)$, and a positive dose-response rate $(P<0.05)$ were observed. The results of the different assays were analyzed via the SALANAL program (Salmonella Assay Analysis, version 1.0, Integrated Laboratory Systems of Research Triangle Institute, RTP, North Carolina, USA). The choice between linear regression and the Bernstein model [23] was made to allow the elimination of data for doses 
TABLE 1: Collection sites, air volume, PM $2.5 \mu \mathrm{m}$ concentration, and extractable organic matter (EOM) of the samples analyzed.

\begin{tabular}{|c|c|c|c|c|c|}
\hline Site & Month & $\begin{array}{l}\text { Air volume } \\
\left(\mathrm{m}^{3}\right) \pm \text { S.D. }\end{array}$ & $\begin{array}{c}\text { PM } 2.5 \mu \mathrm{m} \text { individual values } \\
\left(\mu \mathrm{g} / \mathrm{m}^{3}\right)\end{array}$ & $\begin{array}{c}\text { PM } 2.5 \mu \mathrm{m} \\
\left(\mu \mathrm{g} / \mathrm{m}^{3}\right) \pm \text { S.D. }\end{array}$ & $\begin{array}{c}\text { EOM } \\
\left(\mu \mathrm{g} / \mathrm{m}^{3}\right)\end{array}$ \\
\hline \multirow{3}{*}{1} & August & $1513 \pm 36$ & $17.51 / 18.63 / 13.63 / 45.09$ & $23.71 \pm 14.41$ & 9.66 \\
\hline & September & $1582 \pm 53$ & $23.43 / 43.83 / 40.24 / 14.48$ & $30.49 \pm 13.89$ & 7.92 \\
\hline & October & $1623 \pm 148$ & $14.46 / 13.61 / 21.73 / 11.27$ & $15.27 \pm 4.51$ & 5.54 \\
\hline \multirow{3}{*}{2} & August & $1541 \pm 1$ & $40.19 / 44.59 / 44.01 / 51.77$ & $45.14 \pm 4.83$ & 7.76 \\
\hline & September & $1554 \pm 31$ & $13.76 / 34.66 / 41.58 / 15.20$ & $26.30 \pm 13.94$ & 7.24 \\
\hline & October & $1640 \pm 194$ & $22.48 / 36.47 / 11.74 / 25.08$ & $23.94 \pm 10.15$ & 5.48 \\
\hline \multirow{3}{*}{3} & August & $430 \pm 67$ & $42.38 / 168.85 / 35.60 / 131.33$ & $94.54 \pm 66.00$ & 20.93 \\
\hline & September & $420 \pm 40$ & 68.85/167.33/91.55/61.01 & $97.18 \pm 48.52$ & 21.44 \\
\hline & October & $359 \pm 6$ & 77.15/239.77/75.68/138.33 & $132.73 \pm 77.09$ & 25.05 \\
\hline
\end{tabular}

1: UERJ; 2: Avenida Brasil; 3: Rebouças tunnel; S.D.: standard deviation; airborne PM $2.5 \mu \mathrm{m}$ samples were collected for $24 \mathrm{~h}$ at sites 1 and 2 and $6 \mathrm{~h}$ at site 3. Six-h time filter saturation at site 3 .

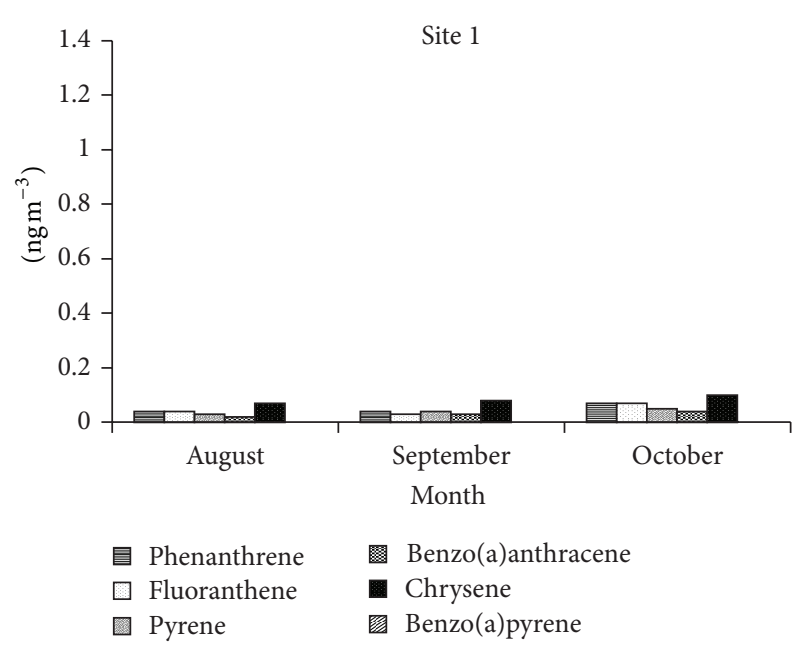

(a)

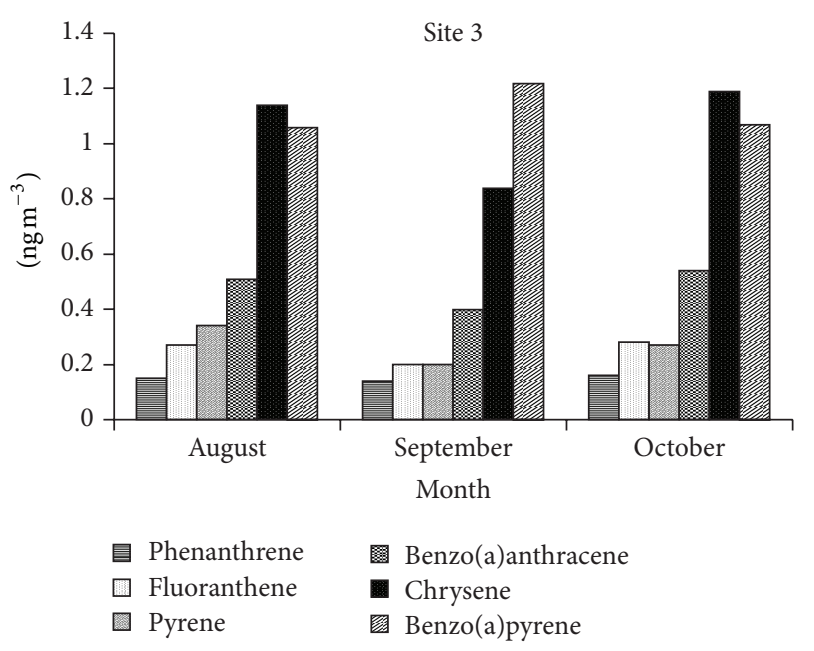

(c)

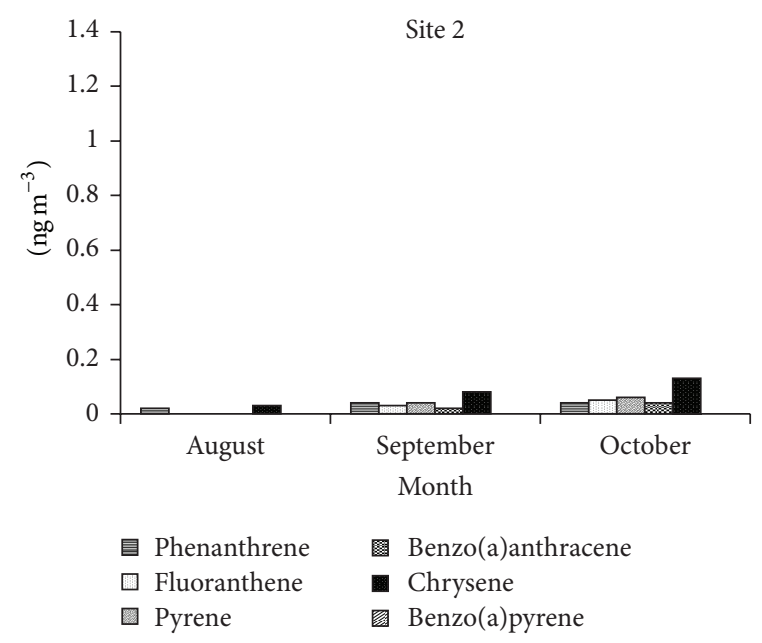

(b) 
outside the linear portion of the dose-response curve. Positive results were interpreted as presenting significant mutagenicity. Positive responses were expressed as the number of revertants per volume of air sampled $\left(\mathrm{rev} / \mathrm{m}^{3}\right)$, that is, $\mathrm{rev} / \mu \mathrm{g}$ multiplied by EOM in $\mu \mathrm{g} / \mathrm{m}^{3}$. In the cytotoxicity test, the solution containing the sample and the bacterial culture (100200 cells) were plated on nutrient agar plates and incubated at $37^{\circ} \mathrm{C}$ for $24 \mathrm{~h}$, and the surviving colonies were counted. The sample was considered cytotoxic if the percentage of surviving cells was less than $60 \%$ of the negative control at one or more doses [18].

2.5. Allium cepa. Onions (Allium cepa L., $2 n=16$ ) were obtained commercially and were placed in small jars with their basal ends dipped in distilled water. The newly sprouted roots (1-2 cm in length) were treated with organic extract of PM $(5 ; 10 ; 15 ; 20$ and $25 \mu \mathrm{g} / \mathrm{mL})$ for $24 \mathrm{~h}$. DMSO was used as a negative control and benzo(a)pyrene $(10 \mu \mathrm{g} / \mathrm{mL})$ as a positive control. The roots were exposed to treatment with organic extract and the controls for $24 \mathrm{~h}$. Afterwards, the roots were removed from the bulbs and hydrolyzed with $\mathrm{HCl} 1 \mathrm{~N}$ : acetic acid $45 \%(1: 9)$ at $50^{\circ} \mathrm{C}$ for $5 \mathrm{~min}$. The hydrolyzed root tips were squashed and stained with $2 \%$ aceto-orcein $[24,25]$. Cytological abnormalities like micronuclei (MCN), bridges, breaks, and laggards were analyzed. The mitotic index (MI) was calculated for each treatment as the number of dividing cells per 1000 cells.

\section{Results and Discussion}

3.1. Airborne Particulate Matter. Table 1 shows the air volume $\left(\mathrm{m}^{3}\right)$, PM $2.5 \mu \mathrm{m}$ concentration $\left(\mu \mathrm{g} / \mathrm{m}^{3}\right)$, and extractable organic matter (EOM) $\left(\mu \mathrm{g} / \mathrm{m}^{3}\right)$ of the samples analyzed from the different sites.

The highest average PM $2.5 \mu \mathrm{m}$ values were detected at site 3 (94.54 to $132.73 \mu \mathrm{g} \mathrm{m}^{-3}$ ), followed by site 2 (26.30; $\left.45.14 \mu \mathrm{g} / \mathrm{m}^{3}\right)$ and site $1\left(30.49 \mu \mathrm{g} / \mathrm{m}^{3}\right)$ (Table 1$)$. The WHO has suggested that the maximum PM 2.5 concentration without incurring health risks is $25 \mu \mathrm{g} / \mathrm{m}^{3}$ (24-hour mean) [26]. It has been demonstrated that for each $10 \mu \mathrm{g} / \mathrm{m}^{3}$ increase in PM concentration, the risk of mortality from cardiopulmonary diseases increases $6 \%$, while the risk of mortality from lung cancer rises $8 \%$ [27]. High levels of PM 2.5 were also detected in a previous study conducted from April to July 2010 at these same sites. The PM concentrations (site $3: 93 \mu \mathrm{g} / \mathrm{m}^{3}$; site 2: $34-60 \mu \mathrm{g} / \mathrm{m}^{3}$; site $1: 25 \mu \mathrm{g} / \mathrm{m}^{3}$ ) reveal the persistence of this pollutant [15]. In both studies, the highest concentrations of PM $2.5 \mu \mathrm{m}$ were detected at site 3 . A study performed in Wutong tunnel in Shenzhen city, China detected PM 2.5 concentrations of $110.8 \mu \mathrm{g} / \mathrm{m}^{3}$ [28]. Both these results can be attributed to intense traffic and poor ventilation in tunnels. The implementation of road space rationing measures and improved ventilation could reduce the concentration of PM 2.5 in these tunnels.

In urban areas, high concentrations of PM derive mainly from motor vehicle emissions. In Rio de Janeiro city, vehicles account for $77 \%$ of emissions [29]. Despite improvements in the quality of fuels, high concentrations of PM are still detected in the city. This is due to the increased fleet of vehicles in the city, which over the last twenty years, has tripled from 838,521 to 2,529,432 [30]. Other urban areas with intense traffic also show high levels of PM 2.5: Beijing, China $\left(66 \mu \mathrm{g} / \mathrm{m}^{3}\right)$ [31], Mexico City $\left(47.20 \mu \mathrm{g} / \mathrm{m}^{3}\right)$ [32], Palermo, Italy $\left(34.20 \mu \mathrm{g} / \mathrm{m}^{3}\right)[33]$, and Coimbatore, India $\left(57.93 \mu \mathrm{g} / \mathrm{m}^{3}\right)$ [34]. The use of clean fuels and improved public transport are the best solutions for this problem, since they would result in lower PM emissions in urban areas.

3.2. Analysis of Polycyclic Aromatic Hydrocarbons (PAHs). Figure 1 shows $\mathrm{PAH}$ concentrations in $\mathrm{ng} / \mathrm{m}^{3}$ at the three sites.

In this study, the six PAHs evaluated are considered a priority in environmental monitoring [35]. PAHs are formed due to incomplete combustion [28]. A lot of effort has been invested in understanding their emissions, dynamic formation mechanisms, and atmospheric behavior. Exhausts from diesel fuel combustion and gasoline engines are a major source of PAH in the atmosphere $[28,36]$. Urban traffic is the biggest contributor to PAH emissions in Rio de Janeiro city. Site 3 showed the highest concentrations of PAH; these results are in agreement with results obtained in July of the same year, for this same site [37]. These results too are in agreement with results obtained in other urban areas. In Europe, for example, the concentration of benzo(a)pyrene in high traffic areas varies from 1 to $5 \mathrm{ng} / \mathrm{m}^{3}$ [38]. In Sweden, in particular, the concentration of benzo(a)pyrene ranges from 1 to $2 \mathrm{ng} / \mathrm{m}^{3}$. These data have prompted political leaders in this country to stipulate a target concentration limit of $0.1 \mathrm{ng} / \mathrm{m}^{3}$ for benzo[a]pyrene [39]. In our results, benzo(a)pyrene was detected only in site 3 at a concentration of between 1.06 and $1.22 \mathrm{ng} / \mathrm{m}^{3}$. The fact that site 3 is enclosed and poorly ventilated may favor the accumulation of this PAH.

Sites 1 and 2 showed the lowest concentrations of the PAH studied. These results could be attributed to the fact that Rio de Janeiro is a coastal city, and the sea serves as an effective dispersant of pollutants [37, 40].

3.3. Salmonella/Microsome Assay. Table 2 shows the mutagenicity data for the organic extracts from airborne particulate matter in rev/ $\mathrm{m}^{3}$. Cytotoxic effects were not detected for any of the samples analyzed.

Mutagenic frameshift responses in the presence of metabolic activation were detected at sites 1 (August and September), 2 (August), and 3 (August, September, and October) (Table 2). These results can be attributed to the presence of promutagens such as PAH detected in this study. Highest mutagenic frameshift responses in the presence of metabolic activation were detected at site 3; this result may be related to high concentrations of PAH (Figure 1), resulting from intense emission by vehicles in this area of the city. Sites 1 (August) and 2 (August), winter season, showed higher values for $\mathrm{rev} / \mathrm{m}^{3}$ than in April and May, autumn season, of the same year [15]. These results suggest that winter season, which is a dry season with low rainfall season, favors the 
TABLE 2: Induced mutagenic by airborne particulate matter organic extracts (rev/ $\left.\mathrm{m}^{3}\right)$.

\begin{tabular}{|c|c|c|c|c|c|c|c|}
\hline \multirow{2}{*}{ Site } & \multirow{2}{*}{ Month } & \multicolumn{2}{|c|}{ TA98 } & \multicolumn{2}{|c|}{ YG1021 } & \multicolumn{2}{|c|}{ YG1024 } \\
\hline & & -S9 & $+\mathrm{S} 9$ & $-S 9$ & $+\mathrm{S} 9$ & $-\$ 9$ & $+\mathrm{S} 9$ \\
\hline \multirow{3}{*}{1} & August & n.d. ${ }^{a}$ & $15.80 \pm 1.40$ & $13.90 \pm 0.80$ & $9.50 \pm 1.40$ & $38.20 \pm 1.60$ & $15.50 \pm 1.40$ \\
\hline & September & n.d. ${ }^{a}$ & $13.00 \pm 2.10$ & $6.10 \pm 1.30$ & n.d. ${ }^{a}$ & $15.80 \pm 2.50$ & $3.40 \pm 0.80$ \\
\hline & October & n.d. ${ }^{a}$ & n.d. ${ }^{a}$ & $10.20 \pm 1.30$ & $6.40 \pm 1.10$ & $2.90 \pm 0.60$ & n.d. ${ }^{a}$ \\
\hline \multirow{3}{*}{2} & August & $17.00 \pm 1.90$ & $1.50 \pm 0.50$ & $17.30 \pm 1.80$ & $5.70 \pm 1.60$ & $43.40 \pm 8.50$ & $10.70 \pm 1.80$ \\
\hline & September & $5.70 \pm 0.90$ & n.d. ${ }^{a}$ & $13.90 \pm 1.30$ & $6.40 \pm 1.24$ & $11.70 \pm 2.50$ & $6.00 \pm 0.70$ \\
\hline & October & n.d. ${ }^{a}$ & n.d. ${ }^{a}$ & $4.90 \pm 0.70$ & n.d. ${ }^{a}$ & $3.80 \pm 0.30$ & n.d. ${ }^{\mathrm{a}}$ \\
\hline \multirow{3}{*}{3} & August & $39.60 \pm 11.90$ & $13.00 \pm 2.30$ & $4.40 \pm 1.90$ & $3.10 \pm 0.80$ & $28.30 \pm 3.10$ & $2.30 \pm 0.80$ \\
\hline & September & $56.40 \pm 20.60$ & $58.70 \pm 11.80$ & $63.00 \pm 3.20$ & $26.60 \pm 3.90$ & $57.00 \pm 6.90$ & $49.30 \pm 3.90$ \\
\hline & October & $9.30 \pm 1.80$ & $46.50 \pm 4.20$ & $35.40 \pm 0.80$ & $18.30 \pm 1.80$ & $22.80 \pm 2.00$ & $6.00 \pm 2.00$ \\
\hline
\end{tabular}

1: UERJ; 2: Avenida Brasil; 3: Rebouças tunnel. n.d. ${ }^{\mathrm{a}}$ : not detected. Negative control: DMSO for the mutagenicity assay without S9 mix was TA98, (28 \pm 5 ); YG1021, (20 \pm 2); YG1024, (18 \pm 4). DMSO for the mutagenicity assay with S9 mix was TA98, (43 \pm 3); YG1021, (35 \pm 23$)$; YG1024, (18 \pm 5$)$. Positive controls for the mutagenicity assay without S9 mix were 4-nitroquinoline oxide ( $0.5 \mu \mathrm{g} /$ plate) for TA98, (853 \pm 72$)$; YG1021, (719 \pm 75$)$; YG1024, (1021 \pm 54$)$. Positive controls for the mutagenicity assay with S9 mix were 2-aminofluorene (1 $\mu \mathrm{g} / \mathrm{plate})$ for TA98, (214 \pm 42$)$; YG1021, (150 \pm 32$)$; YG1024, (219 \pm 81$)$.

TABLE 3: Mitotic index and percentage of mitosis stages and mitotic aberrations in the root tip cells of $A$. cepa treated with organic extract derived at site 1 .

\begin{tabular}{|c|c|c|c|c|c|c|c|c|c|c|c|}
\hline Month & $\mu \mathrm{g} / \mathrm{mL}$ & Mitotic index & $\% \mathrm{P}$. & $\% \mathrm{M}$ & $\% \mathrm{~A}$. & $\% \mathrm{~T}$. & \% T.A. & $\% \mathrm{MCN}$ & $\%$ Bridge & \% Break & \% Lagging \\
\hline \multirow{6}{*}{ August } & $\mathrm{NC}$ & $0.03 \pm 0.00$ & 1.40 & 0.90 & 0.50 & 1.10 & 0.07 & 0.05 & 0.00 & 0.00 & 0.02 \\
\hline & 5 & $0.04 \pm 0.01$ & $3.20^{*}$ & 0.80 & 0.60 & 0.30 & 0.12 & 0.02 & 0.02 & 0.00 & 0.08 \\
\hline & 10 & $0.02 \pm 0.00^{*}$ & $0.20^{*}$ & 1.00 & 0.40 & 1.00 & 0.35 & 0.20 & 0.10 & 0.00 & 0.05 \\
\hline & 15 & $0.01 \pm 0.01^{*}$ & $0.03^{*}$ & 0.30 & 0.10 & $0.20^{*}$ & 0.55 & 0.55 & 0.00 & 0.00 & 0.00 \\
\hline & 20 & $0.01 \pm 0.01^{*}$ & $0.02^{*}$ & $0.10^{*}$ & $0.03^{*}$ & $0.20^{*}$ & 0.05 & 0.03 & 0.00 & 0.02 & 0.00 \\
\hline & 25 & $0.00 \pm 0.00^{*}$ & $0.00^{*}$ & $0.00^{*}$ & $0.00^{*}$ & $0.00^{*}$ & 0.00 & 0.00 & 0.00 & 0.00 & 0.00 \\
\hline \multirow{6}{*}{ September } & $\mathrm{NC}$ & $0.02 \pm 0.01$ & 0.80 & 0.60 & 0.20 & 0.50 & 0.15 & 0.00 & 0.05 & 0.05 & 0.05 \\
\hline & 5 & $0.04 \pm 0.02$ & 1.10 & 1.30 & 0.80 & 0.50 & 0.54 & 0.04 & 0.20 & 0.08 & 0.22 \\
\hline & 10 & $0.07 \pm 0.03$ & 2.00 & $2.50^{*}$ & $1.50^{*}$ & 1.50 & $1.30^{*}$ & 0.10 & 0.40 & 0.40 & 0.40 \\
\hline & 15 & $0.01 \pm 0.01$ & 0.50 & 0.30 & 0.30 & 1.30 & 0.60 & 0.40 & 0.05 & 0.05 & 0.10 \\
\hline & 20 & $0.06 \pm 0.05$ & 2.00 & 2.00 & 1.00 & 1.40 & $1.08^{*}$ & 0.06 & 0.33 & 0.26 & 0.43 \\
\hline & 25 & $0.01 \pm 0.01$ & 0.50 & 0.50 & 0.10 & 0.30 & 0.28 & 0.03 & 0.06 & 0.16 & 0.03 \\
\hline \multirow{6}{*}{ October } & $\mathrm{NC}$ & $0.02 \pm 0.00$ & 1.40 & 0.40 & 0.00 & 0.00 & 0.10 & 0.08 & 0.00 & 0.02 & 0.00 \\
\hline & 5 & $0.11 \pm 0.05$ & 7.00 & 0.70 & 0.40 & 2.60 & 0.10 & 0.00 & 0.00 & 0.07 & 0.03 \\
\hline & 10 & $0.05 \pm 0.05$ & 2.70 & 0.70 & 0.50 & 1.60 & 0.18 & 0.00 & 0.03 & 0.10 & 0.05 \\
\hline & 15 & $0.06 \pm 0.04$ & 2.60 & 1.30 & 0.30 & 2.30 & $0.29^{*}$ & 0.07 & 0.05 & $0.12^{*}$ & 0.05 \\
\hline & 20 & $0.05 \pm 0.03$ & 2.50 & 1.10 & 0.40 & 0.80 & 0.10 & 0.00 & 0.02 & 0.03 & 0.05 \\
\hline & 25 & $0.06 \pm 0.03$ & 3.20 & 1.00 & 0.50 & 1.00 & 0.31 & 0.03 & 0.00 & 0.18 & 0.10 \\
\hline
\end{tabular}

P.: prophase; M.: metaphase; A.: anaphase; T.: telophase; T.A.: total abnormalities; MCN.: micronucleus; NC.: negative control-DMSO; positive control = benzo(a)pyrene $10 \mu \mathrm{g} / \mathrm{mL}$ (mitotic index $=0.00^{*}$; \% T.A. $=0.20 ; \% \mathrm{MCN}=0.16 ; \%$ bridge $\left.=0.04\right)^{*} P \leq 0.05$.

accumulation of pollutants. Similar results were obtained in a study conducted in the city of Rio de Janeiro winter 1984 [41] and July of 2010 [37].

Mutagenic frameshift responses in the absence of metabolic activation were detected at sites 2 (August and September) and 3 (August, September, and October) (Table 2) which indicate the predominance of direct-acting frameshift activity in the airborne particulate material. The occurrence of direct frameshift mutagens adsorbed onto air particulate has been extensively demonstrated in urban samples collected throughout the world, and $\mathrm{PAH}$ derivatives, mainly nitro-PAH and oxygenated $\mathrm{PAH}$, can be implicated [42-44]. These compounds may be derived from the emission of diesel. The highest mutagenic frameshift responses in the absence of metabolic activation values were detected at site 3 . These results may be related to the emission of nitrocompounds at this site. Site 3 shows high flow of buses and trucks, contributing to the emission of compounds derived of diesel. Besides, the absence of pollutant dispersion factors may have contributed to the buildup of these pollutants.

The contribution of nitrocompounds to direct mutagenic activity was investigated through the Salmonella/microsome assay with specific strains YG1021 and YG1024. At the three assessment sites, the increase in mutagenic activity in overexpressing strains, YG1021 and YG1024 compared to the 
TABLE 4: Mitotic index and percentage of mitosis stages and mitotic aberrations in the root tip cells of $A$. cepa treated with organic extract derived at site 2 .

\begin{tabular}{|c|c|c|c|c|c|c|c|c|c|c|c|}
\hline Month & $\mu \mathrm{g} / \mathrm{mL}$ & Mitotic index & $\% \mathrm{P}$. & $\% \mathrm{M}$. & $\% \mathrm{~A}$. & $\% \mathrm{~T}$. & \% T.A. & $\% \mathrm{MCN}$ & $\%$ Bridge & $\%$ Break & \% Lagging \\
\hline \multirow{6}{*}{ August } & $\mathrm{NC}$ & $0.08 \pm 0.03$ & 4.50 & 1.90 & 0.40 & 1.10 & 0.30 & 0.18 & 0.07 & 0.00 & 0.05 \\
\hline & 5 & $0.07 \pm 0.03$ & 3.20 & 1.60 & $0.90^{*}$ & 1.80 & 0.57 & 0.25 & 0.17 & 0.00 & 0.15 \\
\hline & 10 & $0.04 \pm 0.01^{*}$ & $1.80^{*}$ & 0.80 & 0.40 & 0.60 & 0.41 & 0.03 & 0.06 & 0.16 & 0.16 \\
\hline & 15 & $0.04 \pm 0.01^{*}$ & $0.33^{*}$ & 3.26 & 0.56 & 0.36 & $0.75^{*}$ & 0.03 & $0.23^{*}$ & $0.26^{*}$ & 0.23 \\
\hline & 20 & $0.04 \pm 0.02^{*}$ & 2.53 & 1.23 & 0.46 & 0.76 & 0.19 & 0.00 & 0.00 & 0.16 & 0.03 \\
\hline & 25 & $0.04 \pm 0.01^{*}$ & $0.10^{*}$ & 1.40 & $0.90^{*}$ & 1.40 & 0.70 & 0.00 & $0.50^{*}$ & 0.10 & 0.10 \\
\hline \multirow{6}{*}{ September } & $\mathrm{NC}$ & $0.02 \pm 0.01$ & 0.80 & 0.60 & 0.20 & 0.50 & 0.15 & 0.00 & 0.05 & 0.05 & 0.05 \\
\hline & 5 & $0.04 \pm 0.02$ & 1.10 & 1.30 & 0.80 & 0.50 & 0.54 & 0.04 & 0.20 & 0.08 & 0.22 \\
\hline & 10 & $0.07 \pm 0.03$ & 2.00 & $2.50^{*}$ & $1.50^{*}$ & 1.50 & $1.30^{*}$ & 0.10 & 0.40 & 0.40 & 0.40 \\
\hline & 15 & $0.01 \pm 0.01$ & 0.50 & 0.30 & 0.30 & $0.01^{*}$ & 0.60 & 0.40 & 0.05 & 0.05 & 0.10 \\
\hline & 20 & $0.06 \pm 0.05$ & 2.00 & 2.00 & 1.00 & 1.40 & $1.08^{*}$ & 0.06 & 0.33 & 0.26 & 0.43 \\
\hline & 25 & $0.01 \pm 0.01$ & 0.50 & 0.50 & 0.10 & 0.30 & 0.28 & 0.03 & 0.06 & 0.16 & 0.03 \\
\hline \multirow{6}{*}{ October } & $\mathrm{NC}$ & $0.05 \pm 0.02$ & 3.90 & 0.50 & 0.20 & 0.30 & 0.30 & 0.10 & 0.00 & 0.10 & 0.10 \\
\hline & 5 & $0.05 \pm 0.01$ & 2.00 & 1.50 & 0.70 & 1.30 & 0.67 & 0.00 & $0.17^{*}$ & 0.30 & 0.20 \\
\hline & 10 & $0.07 \pm 0.01$ & 1.70 & 1.80 & 0.80 & $3.20^{*}$ & 1.05 & 0.00 & 0.10 & 0.75 & 0.20 \\
\hline & 15 & $0.00 \pm 0.00$ & 0.00 & 0.00 & 0.00 & 0.00 & 0.00 & 0.00 & 0.00 & 0.00 & 0.00 \\
\hline & 20 & $0.00 \pm 0.00$ & 0.00 & 0.00 & 0.00 & 0.00 & 0.03 & 0.00 & 0.03 & 0.00 & 0.00 \\
\hline & 25 & $0.00 \pm 0.00$ & 0.00 & 0.00 & 0.00 & 0.00 & 0.00 & 0.00 & 0.00 & 0.00 & 0.00 \\
\hline
\end{tabular}

P.: prophase; M.: metaphase; A.: anaphase; T.: telophase; T.A.: total abnormalities; MCN.: micronucleus; NC.: negative control-DMSO; positive control = benzo(a)pyrene $10 \mu \mathrm{g} / \mathrm{mL}$ (mitotic index $=0.00^{*}$; $\%$ T.A. $=0.20$; $\%$ bridge $=0.10$; $\%$ break $=0.10$ ) ${ }^{*} P \leq 0.05$.

TABle 5: Mitotic index and percentage of mitosis stages and mitotic aberrations in the root tip cells of $A$. cepa treated with organic extract derived at site 3 .

\begin{tabular}{|c|c|c|c|c|c|c|c|c|c|c|c|}
\hline Month & $\mu \mathrm{g} / \mathrm{mL}$ & Mitotic index & $\% \mathrm{P}$. & $\% \mathrm{M}$. & $\% \mathrm{~A}$. & $\% \mathrm{~T}$. & \% T. A. & $\% \mathrm{MCN}$ & $\%$ Bridge & $\%$ Break & \% Lagging \\
\hline \multirow{6}{*}{ August } & $\mathrm{NC}$ & $0.04 \pm 0.02$ & 2.60 & 0.70 & 0.40 & 1.00 & 0.12 & 0.07 & 0.00 & 0.00 & 0.05 \\
\hline & 5 & $0.03 \pm 0.02$ & 0.70 & 0.40 & 0.90 & 0.30 & 0.30 & 0.04 & 0.02 & 0.00 & 0.14 \\
\hline & 10 & $0.07 \pm 0.03$ & 2.70 & 2.20 & 0.90 & 2.10 & $0.50^{*}$ & 0.30 & 0.10 & 0.00 & 0.10 \\
\hline & 15 & $0.06 \pm 0.04$ & 1.70 & 2.20 & $1.10^{*}$ & 1.00 & 0.26 & 0.10 & 0.13 & 0.00 & 0.03 \\
\hline & 20 & $0.04 \pm 0.02$ & 1.60 & 1.40 & 0.70 & 1.00 & 0.16 & 0.10 & 0.03 & 0.00 & 0.03 \\
\hline & 25 & $0.03 \pm 0.01$ & 1.30 & 0.90 & 0.60 & 0.60 & 0.15 & 0.00 & 0.00 & 0.00 & 0.15 \\
\hline \multirow{6}{*}{ September } & NC & $0.08 \pm 0.06$ & 6.00 & 1.60 & 0.90 & 1.40 & 0.67 & 0.10 & 0.08 & 0.20 & 0.42 \\
\hline & 5 & $0.04 \pm 0.03$ & 3.10 & 1.00 & 0.40 & 2.10 & $2.05^{*}$ & $1.63^{*}$ & 0.12 & 0.22 & 0.05 \\
\hline & 10 & $0.03 \pm 0.03$ & $1.00^{*}$ & 0.80 & 0.40 & 0.60 & 0.78 & 0.25 & 0.03 & 0.20 & 0.30 \\
\hline & 15 & $0.10 \pm 0.10$ & 3.30 & 3.20 & 1.20 & 2.00 & 1.80 & 0.00 & $1.00^{*}$ & 0.60 & 0.20 \\
\hline & 20 & $0.00 \pm 0.00^{*}$ & $0.00^{*}$ & $0.00^{*}$ & 0.00 & 0.00 & 0.00 & 0.00 & 0.00 & 0.00 & 0.00 \\
\hline & 25 & $0.02 \pm 0.01^{*}$ & $1.00^{*}$ & $0.10^{*}$ & 0.00 & 0.70 & 0.12 & 0.00 & 0.00 & 0.10 & 0.02 \\
\hline \multirow{6}{*}{ October } & $\mathrm{NC}$ & $0.08 \pm 0.01$ & 5.70 & 0.70 & 0.60 & 1.20 & 0.30 & 0.00 & 0.05 & 0.05 & 0.20 \\
\hline & 5 & $0.09 \pm 0.01$ & 3.80 & 1.60 & 0.80 & 2.90 & 0.60 & 0.00 & 0.00 & $0.50^{*}$ & 0.10 \\
\hline & 10 & $0.06 \pm 0.05$ & $1.90^{*}$ & 0.70 & 0.40 & 2.70 & 0.28 & 0.10 & 0.03 & 0.05 & 0.10 \\
\hline & 15 & $0.03 \pm 0.01^{*}$ & $0.90^{*}$ & 0.70 & 0.50 & 0.80 & 0.40 & 0.20 & 0.10 & 0.00 & 0.10 \\
\hline & 20 & $0.00 \pm 0.00^{*}$ & $0.00^{*}$ & 0.00 & 0.00 & 0.00 & 0.00 & 0.00 & 0.00 & 0.00 & 0.00 \\
\hline & 25 & $0.01 \pm 0.02^{*}$ & $0.80^{*}$ & 0.00 & 0.03 & 0.03 & 0.33 & 0.00 & 0.03 & 0.00 & 0.00 \\
\hline
\end{tabular}

P.: prophase; M.: metaphase; A.: anaphase; T.: telophase; T.A.: total abnormalities; MCN.: micronucleus; NC.: negative control-DMSO; positive control = benzo(a)pyrene $10 \mu \mathrm{g} / \mathrm{mL}$ (mitotic index $=0.00^{*}$; \% T.A. $=0.00 ; \%$ ) ${ }^{*} \mathrm{P} \leq 0.05$.

parental TA98, indicates the participation of nitroarenes and dinitroarenes in the total mutagenicity of the extracts studied. The presence of nitroarenes weas detected at site 1 (August, September, and October), 2 (August and October), and 3 (September). The presence of dinitroarenes was detected at site 1 (September and October), 2 (August and October), and 3 (September and October). It is well known that when nitrocompounds are implicated, the mutagenic response in the presence of $S 9 \mathrm{mix}$ is decreased compared to the situations without $\mathrm{S} 9 \mathrm{mix}[8,11]$. This is because mammalian 
enzymes reduce nitroarenes all the way to arylamines, and arylamines are not direct-aging mutagens. The mutagenicity of these chemicals can be explained by their reoxidation by cytochrome P450-dependent enzymes to the arylhydroxylamines. However, it must be noted that generally arylamines exhibit a much lower mutagenicity in the presence of $\$ 9$ mix than the corresponding nitroarenes in the absence of $\$ 9$ mix [45].

These nitrocompounds result from direct emissions of diesel combustion and can be produced by atmospheric reactions of $\mathrm{PAH}$ with gaseous copollutants found in photochemical smog $[44,46]$. In Brazil, the presence of nitrocompounds has also been observed in air samples from Rio de Janeiro [15, 37], Porto Alegre [17, 18, 47], and São Paulo $[11,44,48]$.

3.4. Allium cepa. Tables 3, 4, and 5 show the mitotic index, percentage of mitosis stages, and mitotic aberrations in the root tip cells of $A$. cepa treated with organic extract derived from sites 1,2 , and 3 , respectively.

The mitotic root meristems of Allium cepa have been used as cytogenetic materials for clastogenicity studies of physical and chemical agents since the early 1930 s $[49,50]$. In this work, we evaluated organic extracts from different sites of the city of Rio de Janeiro for cytotoxic/proliferation effect and chromosomal abnormalities. A reduced $\mathrm{MI}$ in relation to the negative control could indicate a cytotoxic effect, while a higher MI could be indicative of a proliferative effect [51]. In our results, we detected a cytotoxic effect in organic extracts at site 1 (August) (Table 3), site 2 (August) (Table 4), and site 3 (September to October) (Table 5). The positive control used in the test also presented a cytotoxic effect, as observed in the literature [52]. The reduction in the percentage of mitotic cells in certain stages observed at the three sites may indicate the need to disrupt the mitotic cycle in order to possibly repair the damage caused by the components of the organic extracts.

Chromosome aberrations are characterized by changes in either chromosomal structure or the total number of chromosomes, which can occur both spontaneously and as a result of exposure to physical or chemical agents [14]. Structural chromosomal alterations may be induced by several factors, such as DNA breaks, inhibition of DNA synthesis, and replication of altered DNA $[14,53]$. Two studies conducted in different regions of Yugoslavia to evaluate the occurrence of chromosomal abnormalities in the particulate matter deposited in the snow using the Allium cepa pointed to an increase in chromosomal abnormalities $[54,55]$. Our results are in agreement with data from the literature. We detected significantly increased abnormalities, such as a bridge at site 2 (Table 4) and a micronucleus and bridge at site 3 (Table 5). A significant increase in breaks was observed at all three sites. Bridges noticed in the cells were probably formed by the breakage and fusion of chromosomes and chromatids [25]. Micronuclei are the result of damage in the parental cells, that is, either not repaired or wrongly repaired, and are easily observed in daughter cells as a similar structure to the main nucleus, but in a reduced size [14]. Micronucleus, bridge, and break abnormalities are attributed to clastogenic substances, which indicate that our results may indicate the clastogenic activity of the organic extracts. We call to attention that in some periods, the high concentrations of the extracts lead to a cytotoxic effect that can dissemble a clastogenic effect.

According to [56], a complex mixture of hydrocarbons may present clastogenic and aneugenic activities or even induce cell death in Allium cepa genetic material. The authors also suggest that these actions mainly result from the presence of polycyclic aromatic hydrocarbons (PAHs) detected in the tested sample. Furthermore, Allium cepa assay has also the ability to detect nitrocompounds [25, 52]; therefore, these results may be related to the presence of these compounds in organic extracts.

The cytotoxic effect and the abnormalities detected in the present study can be attributed to the presence of $\mathrm{PAH}$ nitroderivatives in the organic extracts. As a response to the presence of pollutants, Allium cepa has a mechanism involving cytochrome P450- (CYP-) dependent mixed function oxidases with particular reference to ethoxyresorufin- $O$ deethylase (EROD) activity $[57,58]$. According to this mechanism, ligands like $\mathrm{PAH}$ activate the hydrocarbon receptor (AhR), which in its inactive form resides in the cytoplasm in a complex with the molecular chaperones, hsp90 and p23 [59]. CYP1A1 activation may be a result of the weakening of the interactions between AhR and hsp90, thus releasing the AhR to translocate to the nucleus and activate the CYP1A1 gene [58]. This reinforces the ability of this plant species to detect this class of pollutants.

\section{Conclusion}

In conclusion, both PAH and nitroderivatives probably contributed to the detected airborne genotoxicity at different sites of Rio de Janeiro. The information generated in this study shows the importance of simple biological tests such as the Salmonella/microsome and Allium cepa to better characterize air pollution. Evaluation of the genotoxicity of urban airborne particulate matter performed by these tests is important as a basis for decision making by regulatory authorities.

\section{Conflict of Interests}

There is no conflict of interests.

\section{Acknowledgments}

The authors thank Fundação Carlos Chagas Filho de Amparo à Pesquisa do Estado do Rio de Janeiro (FAPERJ, 23/2008), Coordenação de Aperfeiçoamento de Pessoal de Nível Superior (CAPES), and Conselho Nacional de Desenvolvimento Científico e Tecnológico $(\mathrm{CNPq})$ for their financial support and the Rio de Janeiro city departments of education and transportation for their partnership in this work.

\section{References}

[1] M. Sørensen, H. Autrup, P. Møller et al., "Linking exposure to environmental pollutants with biological effects," Mutation Research, vol. 544, no. 2-3, pp. 255-271, 2003. 
[2] T. M. C. M. de Kok, H. A. L. Driece, J. G. F. Hogervorst, and J. J. Briedé, "Toxicological assessment of ambient and trafficrelated particulate matter: a review of recent studies," Mutation Research, vol. 613, no. 2-3, pp. 103-122, 2006.

[3] N. Gouveia, G. A. S. Mendonça, A. P. Leon et al., "Poluição do ar e efeitos na saúde nas populações de duas grandes metropóles brasileiras," Epidemiologia e Serviços de Saúde, vol. 12, pp. 29240, 2003.

[4] W. L. Junger, A. P. Leon, and G. A. S. Mendonça, "Associação entre mortalidade diária por câncer de pulmão e poluição do ar no município do Rio de Janeiro: um estudo ecológico de séries temporais," Revista Brasileira de Cancerologia, vol. 51, pp. 111115, 2005.

[5] H. A. Castro, M. F. Cunha, G. A. S. Mendonça, W. L. Junger, J. C. Cruz, and A. P. Leon, "Efeitos da poluição do ar na função respiratória de escolares, Rio de Janeiro, RJ," Revista Saúde Pública, vol. 43, pp. 26-34, 2009.

[6] M. Moura, W. L. Junger, G. A. E. S. Mendonça, and A. P. de Leon, "Air quality and emergency pediatric care for symptoms of bronchial obstruction categorized by age bracket in Rio de Janeiro, Brazil," Caderno Saúde Pública, vol. 25, no. 3, pp. 635644, 2009.

[7] S. M. Oh, H. R. Kim, Y. J. Park, S. Y. Lee, and K. H. Chung, "Organic extracts of urban air pollution particulate matter (PM2.5)-induced genotoxicity and oxidative stress in human lung bronchial epithelial cells (BEAS-2B cells)," Mutation Research, vol. 723, no. 2, pp. 142-151, 2011.

[8] L. D. Claxton, P. P. Matthews, and S. H. Warren, "The genotoxicity of ambient outdoor air, a review: salmonella mutagenicity," Mutation Research, vol. 567, no. 2-3, pp. 347-399, 2004.

[9] T. Enya, H. Suzuki, T. Watanabe, T. Hirayama, and Y. Hisamatsu, "3-Nitrobenzanthrone, a powerful bacterial mutagen and suspected human carcinogen found in diesel exhaust and airborne particulates," Environmental Science and Technology, vol. 31, no. 10, pp. 2772-2776, 1997.

[10] WHO-IPCS INCHEM, "Selected nitro- and nitro-oxypolycyclic aromatic hydrocarbons," Environmental Health Criteria (EHC) Monograph 229, 2003.

[11] G. D. A. Umbuzeiro, A. Franco, D. Magalhães et al., "A preliminary characterization of the mutagenicity of atmospheric particulate matter collected during sugar cane harvesting using the salmonella/microsome microsuspension assay," Environmental and Molecular Mutagenesis, vol. 49, no. 4, pp. 249-255, 2008.

[12] D. M. DeMarini, L. R. Brooks, S. H. Warren, T. Kobayashi, M. I. Gilmour, and P. Singh, "Bioassay-directed fractionation and Salmonella mutagenicity of automobile and forklift diesel exhaust particles," Environmental Health Perspectives, vol. 112, no. 8, pp. 814-819, 2004.

[13] C. H. Marvin and L. M. Hewitt, "Analytical methods in bioassay-directed investigations of mutagenicity of air particulate material," Mutation Research, vol. 636, no. 1-3, pp. 4-35, 2007.

[14] D. M. Leme and M. A. Marin-Morales, "Allium cepa test in environmental monitoring: a review on its application," Mutation Research, vol. 682, no. 1, pp. 71-81, 2009.

[15] C. R. Rainho, A. M. A. Velho, C. A. F. Aiub, S. M. Corrêa, J. L. Mazzei, and I. Felzenszwalb, "Evaluation of urban airborne particulate matter (PM 2.5) in the city of Rio de Janeiro (Brazil) by mutagenicity assays," in Essays on Environmental Studies, A. Sarin, Ed., pp. 1-8, Athens Institute for Education and Research, Athens, Ga, USA, 2012.
[16] V. M. F. Vargas, R. C. Horn, R. R. Guidobono, A. B. Mittelstaedt, and I. G. de Azevedo, "Mutagenic activity of airborne particulate matter from the urban area of Porto Alegre, Brazil," Genetics and Molecular Biology, vol. 21, no. 2, pp. 247-253, 1998.

[17] M. V. Coronas, R. C. Horn, A. Ducatti, J. A. V. Rocha, and V. M. F. Vargas, "Mutagenic activity of airborne particulate matter in a petrochemical industrial area," Mutation Research, vol. 650, no. 2, pp. 196-201, 2008.

[18] T. S. Pereira, G. N. Gotor, L. S. Beltrami et al., "Salmonella mutagenicity assessment of airborne particulate matter collected from urban areas of Rio Grande do Sul State, Brazil, differing in anthropogenic influences and polycyclic aromatic hydrocarbon levels," Mutation Research, vol. 702, no. 1, pp. 78-85, 2010.

[19] S. M. Corrêa and G. Arbilla, "A two-year monitoring program of aromatic hydrocarbons in Rio de Janeiro downtown area," Journal of the Brazilian Chemical Society, vol. 18, no. 3, pp. 539543, 2007.

[20] N. Y. Kado, G. N. Guirguis, C. P. Flessel, R. C. Chan, K. Chang, and J. J. Wesolowski, "Mutagenicity of fine $(<2.5 \mu \mathrm{m})$ airborne particles: diurnal variation in community air determined by a Salmonella micro preincubation (microsuspension) procedure," Environmental Mutagenesis, vol. 8, no. 1, pp. 53-66, 1986.

[21] D. M. Maron and B. N. Ames, "Revised methods for the Salmonella mutagenicity test," Mutation Research, vol. 113, no. 3-4, pp. 173-215, 1983.

[22] M. Watanabe, M. Ishidate, and T. Nohmi, "A sensitive method for the detection of mutagenic nitroarenes: construction of nitroreductase-overproducing derivatives of Salmonella typhimurium strains TA98 and TA100," Mutation Research, vol. 216, no. 4, pp. 211-220, 1989.

[23] L. Bernstein, J. Kaldor, J. McCann, and M. C. Pike, "An empirical approach to the statistical analysis of mutagenesis data from the Salmonella test," Mutation Research, vol. 97, no. 4, pp. 267-281, 1982.

[24] G. L. Cabrera and D. M. G. Rodriguez, "Genotoxicity of leachates from a landfill using three bioassays," Mutation Research, vol. 426, no. 2, pp. 207-210, 1999.

[25] C. R. de Rainho, A. Kaezer, C. A. F. Aiub, and I. Felzenszwalb, "Ability of Allium cepa L. root tips and Tradescantia pallida var. purpurea in $N$-nitrosodiethylamine genotoxicity and mutagenicity evaluation," Anais da Academia Brasileira de Ciencias, vol. 82, no. 4, pp. 925-932, 2010.

[26] World Health Organization, Guidelines for Air Quality For Europe, WHO, Geneva, Switzerland, 2nd edition, 2000.

[27] M. Ianistcki, J. Dallarosa, C. Sauer, C. E. Teixeira, and J. da Silva, "Genotoxic effect of polycyclic aromatic hydrocarbons in the metropolitan area of Porto Alegre, Brazil, evaluated by Helix aspersa (Müller, 1774)," Environmental Pollution, vol. 157, no. 7, pp. 2037-2042, 2009.

[28] L. Y. He, M. Hu, X. F. Huang, Y. H. Zhang, B. D. Yu, and D. Q. Liu, "Chemical characterization of fine particles from on-road vehicles in the Wutong tunnel in Shenzhen, China," Chemosphere, vol. 62, no. 10, pp. 1565-1573, 2006.

[29] Instituto Estadual do Ambiente (INEA), "Relatório Anual da Qualidade do Ar do Estado do Rio de Janeiro," 2009, http://www.inea.rj.gov.br/downloads/relatorios/qualidade_ar_ 2009.pdf.

[30] "Só 14 unidades automáticas medem o ar que o carioca respira," http://oglobo.globo.com/rio20/so-14-unidades-automaticas-medem-ar-que-carioca-respira- 4948672.

[31] L. Y. He, M. Hu, X. F. Huang, Y. H. Zhang, and X. Y. Tang, "Seasonal pollution characteristics of organic compounds in 
atmospheric fine particles in Beijing," Science of the Total Environment, vol. 359, pp. 167-176, 2006.

[32] B. L. Valle-Hernández, V. Mugica-Álvarez, E. Salinas-Talavera et al., "Temporal variation of nitro-polycyclic aromatic hydrocarbons in PM10 and PM 2.5 collected in Northern Mexico City," Science of the Total Environment, vol. 408, pp. 5429-5438, 2010.

[33] G. Dongarrà, E. D. Manno, D. Varrica, M. Lombardo, and M. Vultaggio, "Study on ambient concentrations of PM10, PM10-2.5, PM2.5 and gaseous pollutants. Trace elements and chemical speciation of atmospheric particulates," Atmospheric Environment, vol. 44, no. 39, pp. 5244-5257, 2010.

[34] R. Mohanraj, S. Dhanakumar, and G. Solaraj, "Polycyclic aromatic hydrocarbons bound to PM 2.5 in urban Coimbatore, India with emphasis on source apportionment," The Scientific World Journal, vol. 2012, Article ID 980843, pp. 1-8, 2012.

[35] US Environmental Protection Agency, "Estimating Carcinogenic Potency for Mixtures of Polycyclic Organic Matter (POM) for the 1996 National-Scale Assessment," Appendix H-3, Washington, DC, USA, 1996.

[36] S. H. Cadle, P. A. Mulawa, E. C. Hunsanger et al., "Composition of light-duty motor vehicle exhaust particulate matter in the Denver, Colorado area," Environmental Science and Technology, vol. 33, no. 14, pp. 2328-2339, 1999.

[37] C. R. Rainho, A. M. A. Velho, C. A. F. Aiub, S. M. Corrêa, J. L. Mazzei, and L. Felzenszwalb, "Prediction of health risk due to polycyclic aromatic hydrocarbons present in urban air in Rio de Janeiro, Brazil," Genetics and Molecular Research, 2013.

[38] Agency for Toxic Substances and Disease Registry, Toxicological Profile for Polycyclic Aromatichydrocarbons, Agency for Toxic Substances and Disease Registry, Atlanta, Ga, USA, 1995.

[39] C. E. Boström, P. Gerde, A. Hanberg et al., "Cancer risk assessment, indicators, and guidelines for polycyclic aromatic hydrocarbons in the ambient air," Environmental Health Perspectives, vol. 110, no. 3, pp. 451-488, 2002.

[40] M. B. Fernandes, L. S. R. Brickus, J. C. Moreira, and J. N. Cardoso, "Atmospheric BTX and polyaromatic hydrocarbons in Rio de Janeiro, Brazil," Chemosphere, vol. 47, no. 4, pp. 417-425, 2002.

[41] A. G. Miguel, J. M. Daisey, and J. A. Sousa, "Comparative study of the mutagenic and genotoxic activity associated with inhalable particulate matter in Rio de Janeiro air," Environmental and Molecular Mutagenesis, vol. 15, no. 1, pp. 36-43, 1990.

[42] R. Crebelli, S. Fuselli, A. Meneguz et al., "In vitro and in vivo mutagenicity studies with airborne particulate extracts," Mutation Research, vol. 204, no. 4, pp. 565-575, 1988.

[43] M. Adonis and L. Gil, "Mutagenicity of organic extracts from Santiago (Chile) airborne particulate matter," Mutation Research, vol. 292, no. 1, pp. 51-61, 1993.

[44] M. I. Z. Sato, G. A. Umbuzeiro, C. A. Coimbrão et al., "Mutagenicity of airborne particulate organic material from urban and industrial areas of São Paulo, Brazil," Mutation Research, vol. 335, pp. 317-330, 1995.

[45] H. S. Rosenkranz and R. Mermelstein, "Mutagenicity and genotoxicity of nitroarenes. All nitro-containing chemicals were not created equal," Mutation Research, vol. 114, no. 3, pp. 217-267, 1983.

[46] J. N. Pitts Jr., "On the trail of atmospheric mutagens and carcinogens: a combined chemical/microbiological approach," American Zoologist, vol. 25, no. 2, pp. 415-431, 1985.

[47] V. M. F. Vargas, "Mutagenic activity as a parameter to assess ambient air quality for protection of the environment and human health," Mutation Research, vol. 544, no. 2-3, pp. 313-319, 2003.

[48] B. S. de Martinis, N. Y. Kado, L. R. F. de Carvalho, R. A. Okamoto, and L. A. Gundel, "Genotoxicity of fractionated organic material in airborne particles from São Paulo, Brazil," Mutation Research, vol. 446, no. 1, pp. 83-94, 1999.

[49] T. H. Ma, Z. Xu, C. Xu et al., "The improved Allium/Vicia root tip micronucleus assay for clastogenicity of environmental pollutants," Mutation Research, vol. 334, no. 2, pp. 185-195, 1995.

[50] L. D. Claxton and G. M. Woodall, "A review of the mutagenicity and rodent carcinogenicity of ambient air," Mutation Research, vol. 636, no. 1-3, pp. 36-94, 2007.

[51] T. C. C. Fernandes, D. E. C. Mazzeo, and M. A. Marin-Morales, "Mechanism of micronuclei formation in polyploidizated cells of Allium cepa exposed to trifluralin herbicide," Pesticide Biochemistry and Physiology, vol. 88, no. 3, pp. 252-259, 2007.

[52] G. Fiskesjö and C. Lassen, "Benzo[a]pireno and nitrosoguanidine in the Allium test," Mutation Research, vol. 97, p. 188, 1982.

[53] R. J. Albertini, D. Anderson, G. R. Douglas et al., "IPCS guideline for the monitoring of genotoxic effects of carcinogens in humans, International Programme on Chemical Safety," Mutation Research, vol. 463, pp. 111-172, 2000.

[54] K. Al-Sabti, "Allium test for air and water borne pollution control," Cytobios, vol. 58, no. 233, pp. 71-78, 1989.

[55] P. Poli, A. Buschini, F. M. Restivo et al., "Comet assay application in environmental monitoring: DNA damage in human leukocytes and plant cells in comparison with bacterial and yeast tests," Mutagenesis, vol. 14, no. 6, pp. 547-556, 1999.

[56] D. M. Leme, D. D. F. D. Angelis, and M. A. Marin-Morales, "Action mechanisms of petroleum hydrocarbons present in waters impacted by an oil spill on the genetic material of Allium cepa root cells," Aquatic Toxicology, vol. 88, no. 4, pp. 214-219, 2008.

[57] M. J. Moore, I. V. Mitrofanov, S. S. Valentini et al., "Cytochrome P4501A expression, chemical contaminants and histopathology in roach, goby and sturgeon and chemical contaminants in sediments from the Caspian Sea, Lake Balkhash and the Ily River Delta, Kazakhstan," Marine Pollution Bulletin, vol. 46, no. 1, pp. 107-119, 2003.

[58] R. A. Fatima and M. Ahmad, "Allium cepa derived EROD as a potential biomarker for the presence of certain pesticides in water," Chemosphere, vol. 62, no. 4, pp. 527-537, 2006.

[59] J. R. Petrulis and G. H. Perdew, "The role of chaperone proteins in the aryl hydrocarbon receptor core complex," ChemicoBiological Interactions, vol. 141, no. 1-2, pp. 25-40, 2002. 

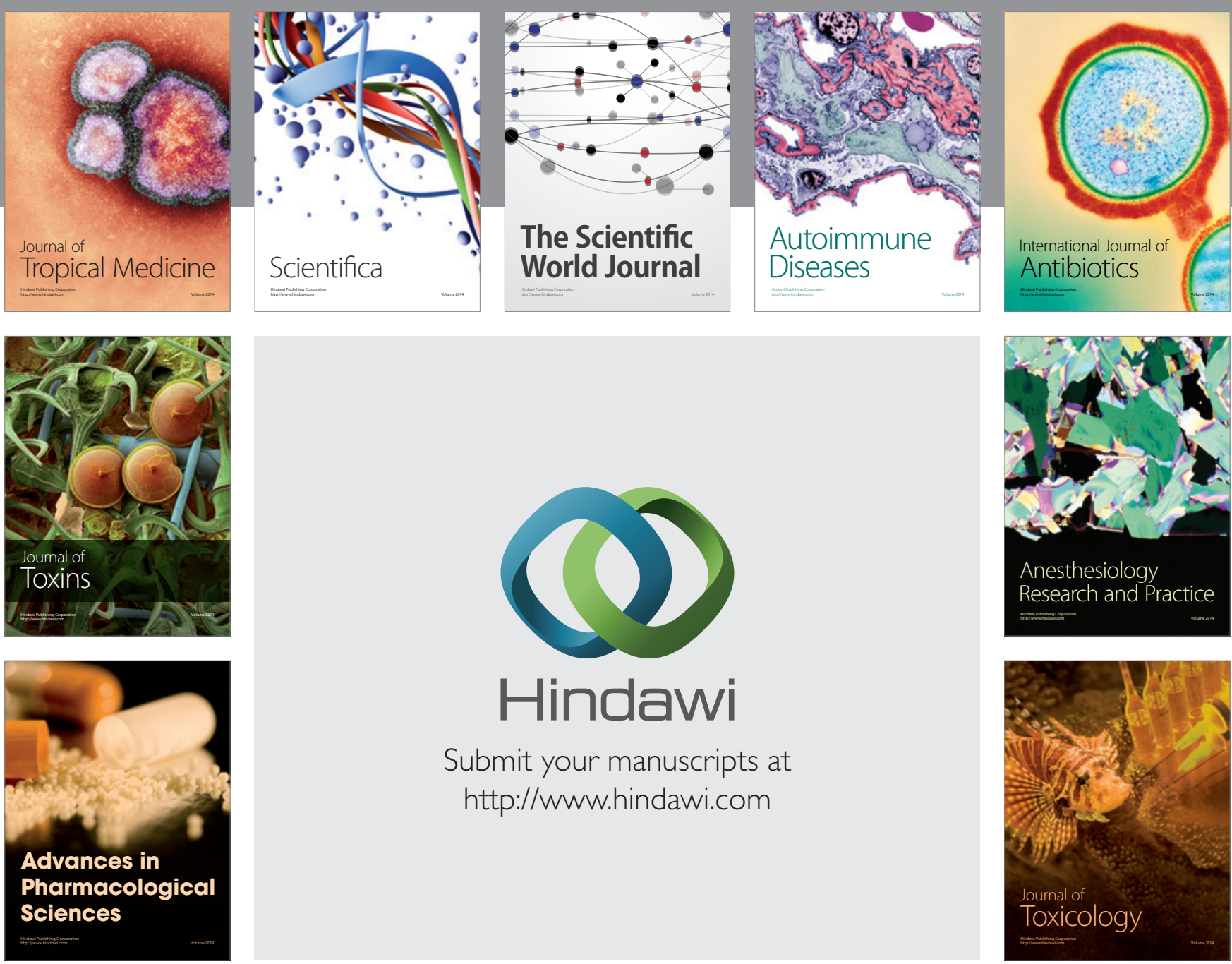

\section{Hindawi}

Submit your manuscripts at

http://www.hindawi.com
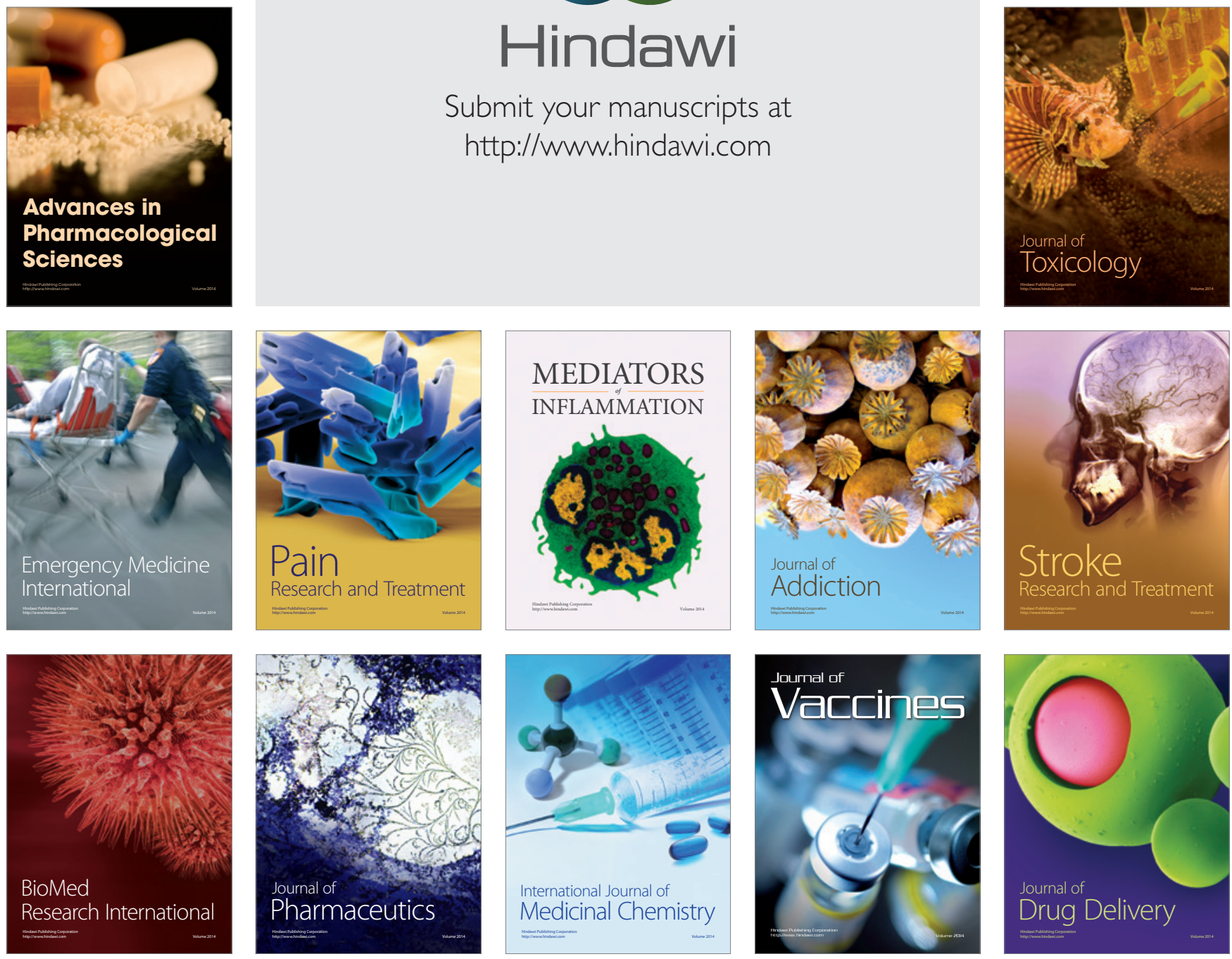